\section{(2) \\ BRAZIULIAN JOURNAL \\ OF MEDICAL AND BIOLOGICAL RESEARCH}

www.bjournal.com.br
ISSN 0100-879X

Volume 45 (6) 473-564 June 2012

BIOMEDICAL SCIENCES

AND

CLINICAL INVESTIGATION

Braz J Med Biol Res, May 2012, Volume 45(6) 482-487

doi: 10.1590/S0100-879X2012007500040

Chi-square analysis of the reduction of ATP levels in L-02 hepatocytes by hexavalent chromium

Yang Yuan, Li Peng, Hu Gong-Hua, Dai Lu, Zhong Xia-Li1, Zhou Yu and Zhong Cai-Gao

The Brazilian Journal of Medical and Biological Research is partially financed by

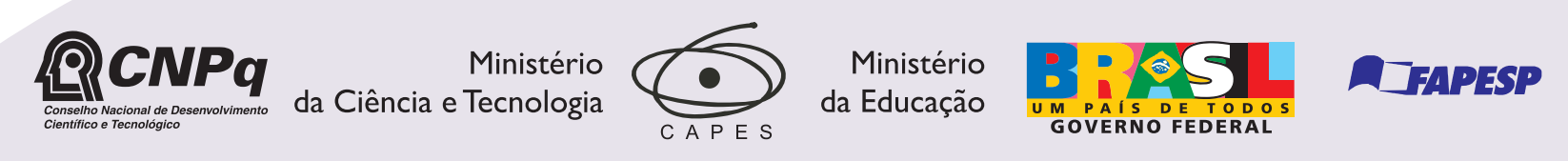

Institutional Sponsors

sompo
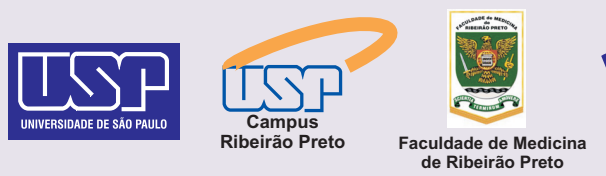

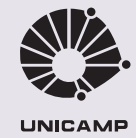

UNICAMP $\oplus$ SHIMADZU

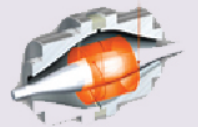

1DI Associaçăo Explore High - Performance MS Orbitrap Technology In Proteomics \& Metabolomics analitica $\underset{\text { analiticaweb.com.br }}{\text { Thermo }}$ 


\title{
Chi-square analysis of the reduction of ATP levels in L-02 hepatocytes by hexavalent chromium
}

\author{
Yang Yuan ${ }^{1,2}$, Li Peng1 ${ }^{1}$, Hu Gong-Hua1 ${ }^{1}$, Dai Lu ${ }^{1}$, Zhong Xia-Li ${ }^{1}$, Zhou Yu1 \\ and Zhong Cai-Gao ${ }^{1}$ \\ ${ }^{1}$ School of Public Health, Central South University, Changsha Hunan, China \\ 2Department of Clinical Laboratory, Huaihua Medical College, Huaihua Hunan, China
}

\begin{abstract}
This study explored the reduction of adenosine triphosphate (ATP) levels in L-02 hepatocytes by hexavalent chromium (Cr(VI)) using chi-square analysis. Cells were treated with 2, 4, 8, 16, or $32 \mu \mathrm{M} \mathrm{Cr}(\mathrm{VI})$ for 12, 24, or $36 \mathrm{~h}$. Methyl thiazolyl tetrazolium (MTT) experiments and measurements of intracellular ATP levels were performed by spectrophotometry or bioluminescence assays following $\mathrm{Cr}(\mathrm{VI})$ treatment. The chi-square test was used to determine the difference between cell survival rate and ATP levels. For the chi-square analysis, the results of the MTT or ATP experiments were transformed into a relative ratio with respect to the control (\%). The relative ATP levels increased at $12 \mathrm{~h}$, decreased at $24 \mathrm{~h}$, and increased slightly again at $36 \mathrm{~h}$ following 4, 8, 16, $32 \mu \mathrm{M} \mathrm{Cr}(\mathrm{VI})$ treatment, corresponding to a "V-shaped" curve. Furthermore, the results of the chi-square analysis demonstrated a significant difference of the ATP level in the $32-\mu \mathrm{M} \mathrm{Cr}(\mathrm{VI})$ group $(\mathrm{P}<0.05)$. The results suggest that the chisquare test can be applied to analyze the interference effects of $\mathrm{Cr}(\mathrm{VI})$ on ATP levels in L-02 hepatocytes. The decreased ATP levels at $24 \mathrm{~h}$ indicated disruption of mitochondrial energy metabolism and the slight increase of ATP levels at $36 \mathrm{~h}$ indicated partial recovery of mitochondrial function or activated glycolysis in L-02 hepatocytes.
\end{abstract}

Key words: Hexavalent chromium; ATP level; Interference effect; Chi-square test

\section{Introduction}

Hexavalent chromium, $\mathrm{Cr}(\mathrm{VI})$, is a well-documented human carcinogen and is widely found in human living environments as the result of industrial production or discharge (1). Recently, $\mathrm{Cr}(\mathrm{VI})$ pollution has been found in crops due to the uptake of $\mathrm{Cr}(\mathrm{VI})$ from the soil and in rivers in some regions of China $(2,3)$. The toxicity caused by oral $\mathrm{Cr}(\mathrm{VI})$ ingestion is thought to be due to toxicity to the liver, which is the main organ of biological metabolism, and liver damage (or hepatotoxicity) from $\mathrm{Cr}(\mathrm{VI})$ exposure has been confirmed in animal experiments and in cultured L-02 hepatocytes, which showed hepatocyte ultrastructure disruption, mitochondrial damage and apoptosis (4-6).

Mitochondria are the main site of ATP synthesis, which is produced by the tricarboxylic acid cycle (TCA) and oxidative phosphorylation (OXPHOS) in the inner mitochondrial membrane (7). At present, the detailed interference effect of $\mathrm{Cr}(\mathrm{VI})$ on the cellular ATP levels is not known. Generally, $\mathrm{Cr}(\mathrm{VI})$ can induce apoptosis and lead to a decrease in cell survival or cell number, and differences in cell number result in the different cellular ATP levels. And in this case manual adjustment of cell number is commonly applied to balance differences in cell number in each group. Small sample $t$-tests or one-way ANOVA were applied to compare the differences between the $\mathrm{Cr}(\mathrm{VI})$ treatment groups and control. However, in our view, adjusting the cell number is not the only way to analyze the toxic effects of $\mathrm{Cr}(\mathrm{VI})$ in vitro. The chi-square statistical test $\left(\mathrm{X}^{2}\right)$ can also be used to analyze the physiological or toxicological effects of $\mathrm{Cr}(\mathrm{VI})$ in vitro.

The $x^{2}$ test is a commonly used statistical method and consists of the Pearson chi-square, linear-by-linear chi-square, McNemar and Mantel-Haenszel tests, among others. Currently, $x^{2}$ analysis is widely applied to compare the difference of a relative ratio existing between two or more groups. It is frequently used in the fields of clinical and experimental epidemiology to explore etiological

Correspondence: Zhong Cai-Gao, School of Public Health, Central South University, Changsha Hunan, 410078 China.

E-mail: zcg54@xysm.net

Received May 21, 2011. Accepted March 9, 2012. Available online March 23, 2012. Published June 4, 2012. 
factors, to assess risk, and to predict trends of disease development. However, the $x^{2}$ test is rarely applied in the field of in vitro cytotoxicity. For this reason, after cultured $\mathrm{L}-02$ hepatocytes were exposed to $0,2,4,8,16$, and $32 \mu \mathrm{M}$ $\mathrm{Cr}(\mathrm{VI})$ for 12,24 , or $36 \mathrm{~h}$, a $\mathrm{X}^{2}$ test was applied to analyze the interference effect by comparing the difference between cell survival rate and intracellular ATP levels to establish a novel method of analyzing the cytotoxicity induced by toxic chemicals in vitro.

\section{Material and Methods}

\section{Material}

Potassium dichromate $\left[\mathrm{K}_{2} \mathrm{Cr}_{2} \mathrm{O}_{7}\right.$, abbreviated as $\left.\mathrm{Cr}(\mathrm{VI})\right]$ was purchased from Sigma (USA). Roswell Park Memorial Institute (RPMI-1640) culture medium was purchased from Solarbio (USA), and newborn calf serum was purchased from Shi Ji Qing (China). A methyl thiazolyl tetrazolium (MTT) cell death kit was purchased from Amresco (USA). The ATP assay kit-S0026 was purchased from Beyotime (China). The human embryonic liver cell line L-02 (L-02 hepatocytes) was obtained from the Shang Hai Center of Cell Culture of Chinese Academy of Sciences. A 0.1 M Cr(VI) stock solution was prepared by adding $29.418 \mathrm{~g} \mathrm{~K}_{2} \mathrm{Cr}_{2} \mathrm{O}_{7}$ to $1000 \mathrm{~mL} \mathrm{ddH} \mathrm{H}_{2} \mathrm{O}$. The stock was then diluted in culture medium to $2,4,8,16,32 \mu \mathrm{M}$.

\section{L-02 hepatocyte culture and $\mathrm{Cr}(\mathrm{VI})$ exposure}

L-02 hepatocytes were cultured on a six-well plate with RPMI-1640 medium containing 15\% newborn calf serum at $37^{\circ} \mathrm{C}$ in a $5 \% \mathrm{CO}_{2}$ atmosphere. The culture medium was changed every $1-2$ days. When the cell density reached $60 \%$ confluence, the cells were exposed to $\mathrm{Cr}(\mathrm{VI})$ for different periods of time $(12,24$, or $36 \mathrm{~h})$ at $37^{\circ} \mathrm{C}$. Untreated cultures were used as a control group. Cell survival was analyzed by the MTT method according to manufacturer instructions.

\section{MTT reduction assay}

The MTT assay was performed according to manufacturer instructions. The growing cells were collected by $0.25 \%$ Trypsin digestion, centrifugation, and supernatant removal. Two milliliters of RPMI-1640 culture medium containing $15 \%$ newborn calf serum was added to resuspend the cells as a single cell suspension. The cell suspension was then inoculated in a 96-well culture plate at a density of $1.0 \mathrm{x}$ $10^{4}$ cells/well. The following day, the cells were grown in medium containing $0,2,4,8,16$, or $32 \mu \mathrm{M} \mathrm{Cr}(\mathrm{VI})$ for 12 , 24 , or $36 \mathrm{~h}$ at $37^{\circ} \mathrm{C}$. Following $\mathrm{Cr}(\mathrm{VI})$ treatment, MTT was added at a volume of $10 \mu \mathrm{L} /$ well and cultured for $4 \mathrm{~h}$ at $37^{\circ} \mathrm{C}$, then $100 \mu \mathrm{L}$ formazan lysate was added, and the cells were cultured for $6 \mathrm{~h}$ at $37^{\circ} \mathrm{C}$. Finally, the 96 -well culture plate was removed from the incubator and continually shaken for $5 \mathrm{~min}$ on a micro-oscillator to completely dissolve the formazan. Immediately, cell vitality was analyzed by measuring absorbance at $492 \mathrm{~nm}$ with a multifunction microplate reader (Thermo Varioskan Flash 3001, USA).

\section{ATP bioluminescence assay}

L-02 hepatocytes were seeded at a density of $2.5 \times 10^{5}$ cells/well on three six-well plates. When the cells reached $60 \%$ confluence, they were exposed to $\mathrm{Cr}(\mathrm{VI})$ for 12,24 , or $36 \mathrm{~h}$. Following $\mathrm{Cr}(\mathrm{VI})$ treatment, intracellular ATP levels were determined using a bioluminescentATP assay kit. The cells were disrupted in $200 \mu \mathrm{L}$ lysis buffer by mechanical disruption, and centrifuged at $12,000 \mathrm{~g}$ to collect the cell supernatant. Meanwhile, an aliquot $(100 \mu \mathrm{L})$ of an ATP detection working solution was added to each well of a black 96-well culture plate and incubated for $3 \mathrm{~min}$ at room temperature. Then, four replicates of $40-\mu \mathrm{L}$ samples of the cell lysate from each group were added to the wells. After allowing the reaction to take place for a few seconds, the luminescence value was measured. In addition, the 96-well plates also contained serial dilutions of an ATP standard solution to generate a standard curve, and the ATP levels in L-02 hepatocytes were calculated by comparison with the ATP standard curve.

\section{Data analysis}

Data were analyzed statistically with Microsoft Office Excel 2003 and SPSS 13.5. The results of the ATP and MTT assays are reported as means \pm SD. The statistical significance of differences between means was determined by an $F$-test (ANOVA analysis) followed by least significant difference (LSD) post hoc tests. The survival rate of the cultured cells (from the MTT assay) and the relative ATP levels are reported as percent (\%) change from control. Statistical significance was determined by Pearson chi-square or linear $x^{2}$ tests. For the purpose of $X^{2}$ analysis, the compared groups were divided by the same number to achieve a gain of less than $100 \%$. A $P$ $<0.05$ values (two-sided test) was accepted as statistically significant.

\section{Results}

\section{Cell viability}

Following treatment with $2,4,8,16$, and $32 \mu \mathrm{M} \mathrm{Cr}(\mathrm{VI})$, L-02 hepatocyte viability decreased progressively over 12,24 , or $36 \mathrm{~h}(\mathrm{P}<0.05)$. The survival rates ranged from 88.20 to $100 \%$ after treatment with low concentrations of $\mathrm{Cr}(\mathrm{VI})(2,4$, and $8 \mu \mathrm{M})$, and the high $\mathrm{Cr}(\mathrm{VI})$ concentrations $(16$ and $32 \mu \mathrm{M})$ led to lower cell survival rates (64.22 to $83.58 \%$ ). Further details from this experiment are shown in Table 1.

\section{ATP level in L-02 hepatocytes}

Following $12 \mathrm{~h}$ of $\mathrm{Cr}(\mathrm{VI})$ treatment, the ATP levels of L-02 hepatocytes were increased. However, after $24 \mathrm{~h}$ of treatment, intracellular ATP levels decreased significantly with $\mathrm{Cr}(\mathrm{VI})$ exposure, except for a slight increase in the 2- 
Table 1. Effect of $\mathrm{Cr}(\mathrm{VI})$ on the viability of L-02 hepatocytes.

\begin{tabular}{|c|c|c|c|c|c|c|c|}
\hline \multirow[t]{3}{*}{ Time } & \multicolumn{6}{|c|}{ MTT absorbance/survival rate (\%) } & \multirow[t]{3}{*}{$x^{2}$ test $(P$ value $)$} \\
\hline & \multicolumn{6}{|c|}{$\mathrm{Cr}(\mathrm{VI})(\mu \mathrm{M})$} & \\
\hline & 0 & 2 & 4 & 8 & 16 & 32 & \\
\hline $12 \mathrm{~h}$ & $\begin{array}{c}0.536 \pm 0.08 \\
(100)\end{array}$ & $\begin{array}{c}0.512 \pm 0.02 \\
(95.52)\end{array}$ & $\begin{array}{c}0.491 \pm 0.03 \\
(91.60)\end{array}$ & $\begin{array}{c}0.487 \pm 0.05 \\
(90.86)\end{array}$ & $\begin{array}{c}0.448 \pm 0.03 \\
(83.58)\end{array}$ & $\begin{array}{c}0.403 \pm 0.03^{*} \\
(75.19)\end{array}$ & $0.00^{\#}$ \\
\hline $24 \mathrm{~h}$ & $\begin{array}{c}0.523 \pm 0.06 \\
(100)\end{array}$ & $\begin{array}{c}0.516 \pm 0.03 \\
(98.66)\end{array}$ & $\begin{array}{c}0.527 \pm 0.05 \\
(100)\end{array}$ & $\begin{array}{c}0.491 \pm 0.02 \\
(93.88)\end{array}$ & $\begin{array}{c}0.419 \pm 0.06 \\
(80.11)\end{array}$ & $\begin{array}{c}0.346 \pm 0.01^{*} \\
(66.16)\end{array}$ & $0.01^{\#}$ \\
\hline $36 \mathrm{~h}$ & $\begin{array}{c}0.517 \pm 0.08 \\
(100)\end{array}$ & $\begin{array}{c}0.501 \pm 0.04 \\
(96.91)\end{array}$ & $\begin{array}{c}0.506 \pm 0.07 \\
(97.87)\end{array}$ & $\begin{array}{c}0.456 \pm 0.04 \\
(88.20)\end{array}$ & $\begin{array}{c}0.397 \pm 0.03 \\
(76.79)\end{array}$ & $\begin{array}{c}0.332 \pm 0.04^{*} \\
(64.22)\end{array}$ & $0.01^{\#}$ \\
\hline
\end{tabular}

$\mathrm{Cr}(\mathrm{VI})=$ hexavalent chromium; $\mathrm{MTT}=$ methyl thiazolyl tetrazolium. Data are reported as means $\pm \mathrm{SD}$ and percent within parentheses, $N=4$. ${ }^{*} \mathrm{P}<0.05$ (least significant difference multiple comparisons following the $F$-test); $\mathrm{P}<0.05$ for linearity (linear $\mathrm{X}^{2}$ test).

Table 2. ATP levels in L-02 hepatocytes following hexavalent chromium $(\mathrm{Cr}(\mathrm{VI}))$ treatment.

\begin{tabular}{|c|c|c|c|c|c|c|c|}
\hline \multirow[t]{3}{*}{ Time } & \multicolumn{6}{|c|}{ ATP content/relative level (\%) } & \multirow[t]{3}{*}{$\mathrm{X}^{2}$ test ( $\mathrm{P}$ value) } \\
\hline & \multicolumn{6}{|c|}{$\operatorname{Cr}(\mathrm{VI})(\mu \mathrm{M})$} & \\
\hline & 0 & 2 & 4 & 8 & 16 & 32 & \\
\hline $12 \mathrm{~h}$ & $\begin{array}{c}8.44 \pm 0.49 \\
\quad(100)\end{array}$ & $\begin{array}{c}10.26 \pm 0.63^{*} \\
(121.56)\end{array}$ & $\begin{array}{c}9.59 \pm 0.56^{*} \\
(113.62)\end{array}$ & $\begin{array}{c}11.33 \pm 0.26^{*} \\
(134.24)\end{array}$ & $\begin{array}{c}10.92 \pm 0.42^{*} \\
(129.38)\end{array}$ & $\begin{array}{c}11.71 \pm 0.39^{*} \\
(138.74)\end{array}$ & $0.03^{\#}$ \\
\hline $24 \mathrm{~h}$ & $\begin{array}{c}14.77 \pm 0.68 \\
(100)\end{array}$ & $\begin{array}{c}17.22 \pm 0.83^{*} \\
(116.58)\end{array}$ & $\begin{array}{c}10.10 \pm 0.23^{*} \\
(68.38)\end{array}$ & $\begin{array}{c}8.10 \pm 0.22^{*} \\
(54.84)\end{array}$ & $\begin{array}{c}5.32 \pm 0.54^{*} \\
(36.02)\end{array}$ & $\begin{array}{c}1.62 \pm 0.09^{*} \\
(10.96)\end{array}$ & $0.00^{\#}$ \\
\hline $36 \mathrm{~h}$ & $\begin{array}{c}19.27 \pm 0.72 \\
(100)\end{array}$ & $\begin{array}{c}18.49 \pm 2.04 \\
(95.96)\end{array}$ & $\begin{array}{c}21.05 \pm 1.87 \\
(109.24)\end{array}$ & $\begin{array}{c}23.79 \pm 0.52^{*} \\
\quad(123.46)\end{array}$ & $\begin{array}{c}16.07 \pm 1.61^{*} \\
(83.40)\end{array}$ & $\begin{array}{c}6.72 \pm 0.09^{*} \\
(34.88)\end{array}$ & 0.15 \\
\hline
\end{tabular}

Data are reported as means $\pm S D$ and percent within parentheses, $N=4$. ${ }^{*} P<0.05$ (least significant difference multiple comparisons following the $F$-test); ${ }^{\#} P<0.05$ for linearity (linear $X^{2}$ test).

$\mu \mathrm{M} \mathrm{Cr}(\mathrm{VI})$ group. Following $36 \mathrm{~h}$ of $\mathrm{Cr}(\mathrm{VI})$ treatment, the low ATP levels showed a slight up-regulation, while the ATP levels in the 16 and $32 \mu \mathrm{M} \mathrm{Cr}(\mathrm{VI})$ groups remained lower than control. The graphic change of relative ATP levels was described as a "V-shaped" curve (Table 2, Figure 1).

\section{$\mathrm{X}^{2}$ analyses comparing cell survival rate and relative ATP levels}

Following $12 \mathrm{~h}$ of $\mathrm{Cr}(\mathrm{VI})$ treatment, the $\mathrm{X}^{2}$ test showed a significant difference in ATP levels in the 8, 16, and 32 $\mu \mathrm{M}$ groups $(\mathrm{P}<0.05)$. Following $24 \mathrm{~h}$ of $\mathrm{Cr}(\mathrm{VI})$ treatment, the $X^{2}$ test showed a significant difference in ATP levels in the $4,8,16$, and $32 \mu \mathrm{M}$ groups $(P<0.05)$. Following $36 \mathrm{~h}$ of $\mathrm{Cr}(\mathrm{VI})$ treatment, the $\mathrm{X}^{2}$ test showed a significant difference in ATP levels in the 8 and $32 \mu \mathrm{M} \mathrm{Cr}(\mathrm{VI})$ groups $(\mathrm{P}<$ 0.05) (Table 3).

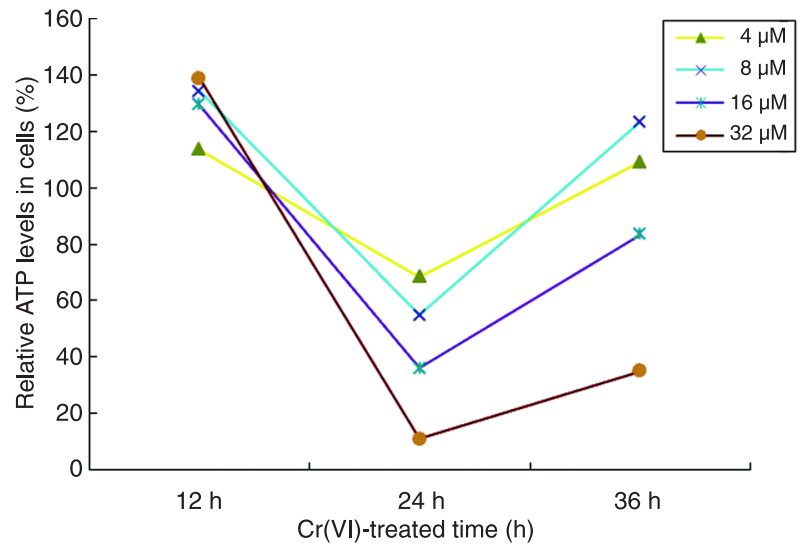

Figure 1. Relative ATP levels in L-02 hepatocytes following hexavalent chromium $(\mathrm{Cr}(\mathrm{VI}))$ treatment. 
Table 3. $x^{2}$ analysis of ATP level and cell viability of L-02 hepatocytes after treatment with hexavalent chromium $(\mathrm{Cr}(\mathrm{VI}))$ for 12,24 , and $36 \mathrm{~h}$.

\begin{tabular}{|c|c|c|c|c|c|c|c|}
\hline \multirow{2}{*}{$\begin{array}{l}\text { Concentration of } \\
\mathrm{Cr}(\mathrm{VI})(\mu \mathrm{M}) \\
12 \mathrm{~h}\end{array}$} & \multirow{2}{*}{ Cell survival rate (\%) } & \multicolumn{6}{|c|}{ Relative level of ATP in cells (\%) } \\
\hline & & 100.00 & 121.56 & 113.62 & 134.24 & 129.38 & 138.74 \\
\hline 0 & 100.00 & 1.000 & & & & & \\
\hline 2 & 95.52 & & 0.065 & & & & \\
\hline 4 & 91.60 & & & 0.120 & & & \\
\hline 8 & 90.86 & & & & $0.002^{*}$ & & \\
\hline 16 & 83.58 & & & & & $0.001^{*}$ & \\
\hline 32 & 75.19 & & & & & & $0.000^{*}$ \\
\hline $24 \mathrm{~h}$ & & 100.00 & 116.58 & 68.38 & 54.84 & 36.02 & 10.96 \\
\hline 0 & 100.00 & 1.000 & & & & & \\
\hline 2 & 98.66 & & 0.202 & & & & \\
\hline 4 & 100.00 & & & $0.022^{*}$ & & & \\
\hline 8 & 93.88 & & & & $0.003^{*}$ & & \\
\hline 16 & 80.11 & & & & & $0.000^{*}$ & \\
\hline 32 & 66.16 & & & & & & $0.000^{*}$ \\
\hline $36 \mathrm{~h}$ & & 100.00 & 95.96 & 109.24 & 123.46 & 83.40 & 34.88 \\
\hline 0 & 100.00 & 1.000 & & & & & \\
\hline 2 & 96.91 & & 0.887 & & & & \\
\hline 4 & 97.87 & & & 0.396 & & & \\
\hline 8 & 88.20 & & & & $0.011^{*}$ & & \\
\hline 16 & 76.79 & & & & & 0.564 & \\
\hline 32 & 64.22 & & & & & & $0.014^{*}$ \\
\hline
\end{tabular}

${ }^{*} \mathrm{P}<0.05$ between ATP relative level and survival rate.

\section{Discussion}

$\mathrm{Cr}(\mathrm{VI})$ is a common environmental pollutant that is widely used in electroplating, metal refining, printing, dyeing, tanning, and other industrial and agricultural processes, and its carcinogenicity has been documented by the International Research Agency of Cancer (IRAC) (1). In China, epidemiological studies suggested that occupational $\mathrm{Cr}(\mathrm{VI})$ exposure led to chronic damage of liver, lung, nasal mucosa, skin and other organs, and an increased risk of cancer incidence (8-10). Furthermore, the study of $\mathrm{Cr}(\mathrm{VI})$ cytotoxicity revealed that $\mathrm{Cr}(\mathrm{VI})$ could readily cross the cell membrane through nonspecific anion channels, resulting in excessive generation of reactive oxygen species. Consequently, induced oxidative stress, genetic damage, mitochondrial dysfunction, activation of apoptosis-related caspases, and mitochondrial-mediated apoptosis were observed (11-13), while chromium-induced genotoxicity and apoptosis were closely associated with $\mathrm{Cr}(\mathrm{VI})$ carcinogenesis (14).

Mitochondria are the main site of ATP synthesis, which is produced mainly through the TCA cycle and OXPHOS, named as mitochondrial aerobic respiration (7). Under normal physiological conditions, mitochondrial aerobic respira- tion is the main way of energy provision, while glycolysis in the cytoplasm is negligible due to the low effectiveness of ATP production (7). Interestingly, the glycolysis metabolism is activated as a compensatory means of energy production existing in many cancer cells (15-17). At present, it is unclear whether toxic chemicals cause also the activation of glycolysis in the process of toxicity. In an adverse environment of exposure to toxic chemicals, several studies have shown that the disorder of energy metabolism induced by toxic chemicals was closely associated with mitochondrial dysfunction. For example, acute ethanol exposure led to suppression of mitochondrial ATP generation and fatty acid oxidation and decreased respiration and accessibility of mitochondrial adenylate kinase in permeabilized hepatocytes $(18,19)$. Exposure to 5 and $10 \mu \mathrm{M} \mathrm{Pb}$ reduced decreased cellular ATP levels in the neuronal cell lines PC-12 and SH-SY5Y, which correlated with voltage-dependent anion channel (VDAC) transcription and expression (20). VDAC is an important protein located on the outer mitochondrial membrane, which controls mitochondrial life and death (21). At present, the effect of $\mathrm{Cr}(\mathrm{VI})$ hepatotoxicity on cellular ATP levels remains ambiguous; therefore, it is important to elucidate the interference effect of $\mathrm{Cr}(\mathrm{VI})$ on ATP levels 
in L-02 hepatocytes.

Different doses of $\mathrm{Cr}(\mathrm{VI})$ can lead to differences in cell survival rates and cell number from control and consequently alter intracellular ATP levels. Therefore, it was interesting to scientifically evaluate the interference effect of $\mathrm{Cr}(\mathrm{VI})$ on ATP level in cells. For the first time, a chi-square test was used to analyze experimental data on the toxicity of $\mathrm{Cr}(\mathrm{VI})$, which is a novel method of analysis of the toxicological effects induced by $\mathrm{Cr}(\mathrm{VI})$. Chi-square testing was applied to compare differences between cell survival rates and ATP levels. If there were significant differences between the variables, this would indicate that the change in intracellular ATP levels is not related to changes in cellular survival rates, which could indicate that $\mathrm{Cr}(\mathrm{VI})$ interferes with ATP synthesis in L-02 hepatocytes.

The experimental results showed that $\mathrm{Cr}(\mathrm{VI})$ led to a gradual decrease of cell survival rate in L-02 hepatocytes at 12,24 , or $36 \mathrm{~h}$ of exposure, and the $32 \mu \mathrm{M} \mathrm{Cr}(\mathrm{VI})$ treatment was able to significantly decrease the cell survival rate. Meanwhile, the relative ATP level showed a pattern of $\mathrm{Cr}(\mathrm{VI})$ interference with ATP levels described as an increase at 12 $\mathrm{h}$, a decrease at $24 \mathrm{~h}$, and a new slight increase at $36 \mathrm{~h}$, looking like a "V-shaped" curve. Furthermore, the results of the Pearson $X^{2}$ test showed that doses of 8,16 , and $32 \mu \mathrm{M}$ $\mathrm{Cr}(\mathrm{VI})$ induced a significant increase of ATP levels at $12 \mathrm{~h}$, while 4, 8, 16, and $32 \mu \mathrm{M} \mathrm{Cr}(\mathrm{VI})$ doses induced a significant decrease of ATP at $24 \mathrm{~h}$. However, after $\mathrm{Cr}(\mathrm{VI})$ treatment for $36 \mathrm{~h}$, the ATP levels increassed slightly again, but the

\section{References}

1. International Agency for Researchon Cancer. [Chromium, nickel and welding. IARC Monographs on the evaluation of the carcinogenic risks to humans]. IARC 1990; 51: 49-256.

2. Wang Wei, Liu Dong-hua, Jiang Wu-sheng, Hou Wen-qiang. [Effects of plant growth in the soil polluted by chromium]. Agro-Environ Protection 2002; 21: 257-259.

3. Zhang Dong, Zhu Li-xia, Yin Guo-xun. [Investigation on hexavalent chromium pollution of karst groundwater in $\mathrm{Ji}$ aozuo, China]. Earth Environ 2009; 37: 237-242.

4. Xiao-Ling Zhou, Han Ying-Shi, Ceng Qing-Shan, Wang Xiang-Pu. [Study of mouse liver tissue cytochemistry and morphology induced by acute chromium trioxide exposure]. J Toxicol 1990; 4: 92-94.

5. Zeng Ming, Wang Xiang-Pu, An Fei-Yun, Gao Ze-Xuan, Wang An. [An experimental study on the toxic liver and renal damage induced by chromium]. China Public Health 1999; 15: 869-870.

6. Xiao JW, Zhong CG, Li B. [Study of L-02 hepatocyte apoptosis induced by hexavalent chromium associated with mitochondria function damage]. Wei Sheng Yan Jiu 2006; 35: 416-418

7. Voet D, Voet JG, Pratt CW. Fundamentals of biochemistry. 2nd edn. Hoboken: John Wiley and Sons, Inc.; 2006.

8. Cai Shi-xiong, Huang Mei-yuan, Luo Yu-mei, Fu Zhen-ying, Chui Yu-zhen, Chen Fu-ming. [Survey of malignant tumor
ATP levels in the 16 and $32 \mu \mathrm{M} \mathrm{Cr}(\mathrm{VI})$ groups were still lower than control. In our view, the increase of ATP level at $12 \mathrm{~h}$ indicated activation of mitochondrial aerobic respiration, the decreased ATP levels at $24 \mathrm{~h}$ indicated disruption of mitochondrial energy metabolism and, interestingly, the slight increase of ATP levels at $36 \mathrm{~h}$ indicated partial recovery of mitochondrial function or activated glycolysis in L-02 hepatocytes.

In summary, the $x^{2}$ test enabled us to distinguish the confounding effects of decreased cell survival rate from changes in intracellular ATP content. This study is the first to demonstrate that exposure to $32 \mu \mathrm{M} \mathrm{Cr}(\mathrm{VI})$ leads to a significant increase in cellular ATP at $12 \mathrm{~h}$, a decrease at $24 \mathrm{~h}$, and a slight increase again at $36 \mathrm{~h}$. Furthermore, in future studies, the $x^{2}$ statistical test could also be considered as a reference for exploring cytotoxicity or pharmacological mechanisms of other chemicals. It would be interesting to further explore the molecular mechanism of mitochondrial energy metabolism- or glycolysis-related genes by the $x^{2}$ method during $\mathrm{Cr}(\mathrm{VI})$ toxicity.

\section{Acknowledgments}

Research supported by the Natural Science Foundation of China (\#30972511) and the Science Innovation Project from the Educational Committee of Hunan Province (\#CX2010B098). incidence in chromate salt production workers]. Chinese $J$ Industr Hygiene Occupational Dis 1986; 4: 210-213.

9. Liao Yongling, Zhou Xu, He Chunlan, Tang Yaoyuan, Zou Lunling, Chen ZhiLian, et al. [Survey on occupational diseases of skin and nasopharynx of 233 workers exposed to chromium]. Occup Health 2001; 17: 2-4.

10. Li Deng-jiu, Qian Sheng-feng, Li Liang, Guo Ping, Wang Xiao-fang. [Health survey of chromate salt production workers]. China Occup Safety Health Manag System Certification 2001; 21: 37-39.

11. Kasprzak KS. Oxidative DNA and protein damage in metalinduced toxicity and carcinogenesis. Free Radic Biol Med 2002; 32: 958-967.

12. Valko M, Rhodes CJ, Moncol J, Izakovic M, Mazur M. Free radicals, metals and antioxidants in oxidative stress-induced cancer. Chem Biol Interact 2006; 160: 1-40.

13. Son $Y O$, Hitron JA, Wang $X$, Chang Q, Pan J, Zhang Z, et al. $\mathrm{Cr}(\mathrm{VI})$ induces mitochondrial-mediated and caspase-dependent apoptosis through reactive oxygen species-mediated p53 activation in JB6 Cl41 cells. Toxicol Appl Pharmacol 2010; 245: 226-235.

14. Singh J, Carlisle DL, Pritchard DE, Patierno SR. Chromiuminduced genotoxicity and apoptosis: relationship to chromium carcinogenesis (review). Oncol Rep 1998; 5: 13071318. 
15. Gatenby RA, Gillies RJ. Why do cancers have high aerobic glycolysis? Nat Rev Cancer 2004; 4: 891-899.

16. Elstrom RL, Bauer DE, Buzzai M, Karnauskas R, Harris MH, Plas DR, et al. Akt stimulates aerobic glycolysis in cancer cells. Cancer Res 2004; 64: 3892-3899.

17. Shi DY, Xie FZ, Zhai C, Stern JS, Liu Y, Liu SL. The role of cellular oxidative stress in regulating glycolysis energy metabolism in hepatoma cells. Mol Cancer 2009; 8: 32.

18. Hoek JB, Cahill A, Pastorino JG. Alcohol and mitochondria: a dysfunctional relationship. Gastroenterology 2002; 122: 2049-2063.

19. Holmuhamedov E, Lemasters JJ. Ethanol exposure de- creases mitochondrial outer membrane permeability in cultured rat hepatocytes. Arch Biochem Biophys 2009; 481: 226-233.

20. Prins JM, Park S, Lurie DI. Decreased expression of the voltage-dependent anion channel in differentiated PC-12 and $\mathrm{SH}-\mathrm{SY} 5 \mathrm{Y}$ cells following low-level $\mathrm{Pb}$ exposure. Toxicol Sci 2010; 113: 169-176.

21. Abu-Hamad S, Sivan S, Shoshan-Barmatz V. The expression level of the voltage-dependent anion channel controls life and death of the cell. Proc Natl Acad Sci U S A 2006; 103: $5787-5792$. 